\title{
Acceptability of the female condom after a social marketing campaign in Campinas, Brazil
}

Horizons Program

Follow this and additional works at: https://knowledgecommons.popcouncil.org/departments_sbsr-hiv

Part of the International Public Health Commons, and the Public Health Education and Promotion Commons

How does access to this work benefit you? Let us know!

\section{Recommended Citation}

"Acceptability of the female condom after a social marketing campaign in Campinas, Brazil," Horizons Research Summary. Washington, DC: Population Council, 2001. 


\section{Acceptability of the Female Condom After a Social Marketing Campaign in Campinas, BraziL}

The female condom is a relatively new product that is intended to
serve the dual role of protecting against unwanted pregnancy and sexually transmitted infections (STIs). Recent research has found moderate to high levels of initial trial and acceptance of the female condom among women (WHO 1997; Berquó et al. 1999; Slaviero et al. 2000; Kerrigan et al. 2000). However, information is lacking about its continued use, particular among women at high risk of HIV and other STIs.

The female condom was registered in Brazil in January of 1997 and since then it has been available commercially through DKT, a social marketing organization. In addition to socially marketed female condoms, the Brazilian Ministry of Health has also given female condoms to public health clinics and community organizations to distribute free as part of targeted activities to vulnerable groups of women.

This report summarizes the findings from a study that examined the role of the female condom as a method of protection against HIV/STIs among female sex workers in Campinas, Brazil, who received increased access to the product and information about it through an educational and social marketing intervention.

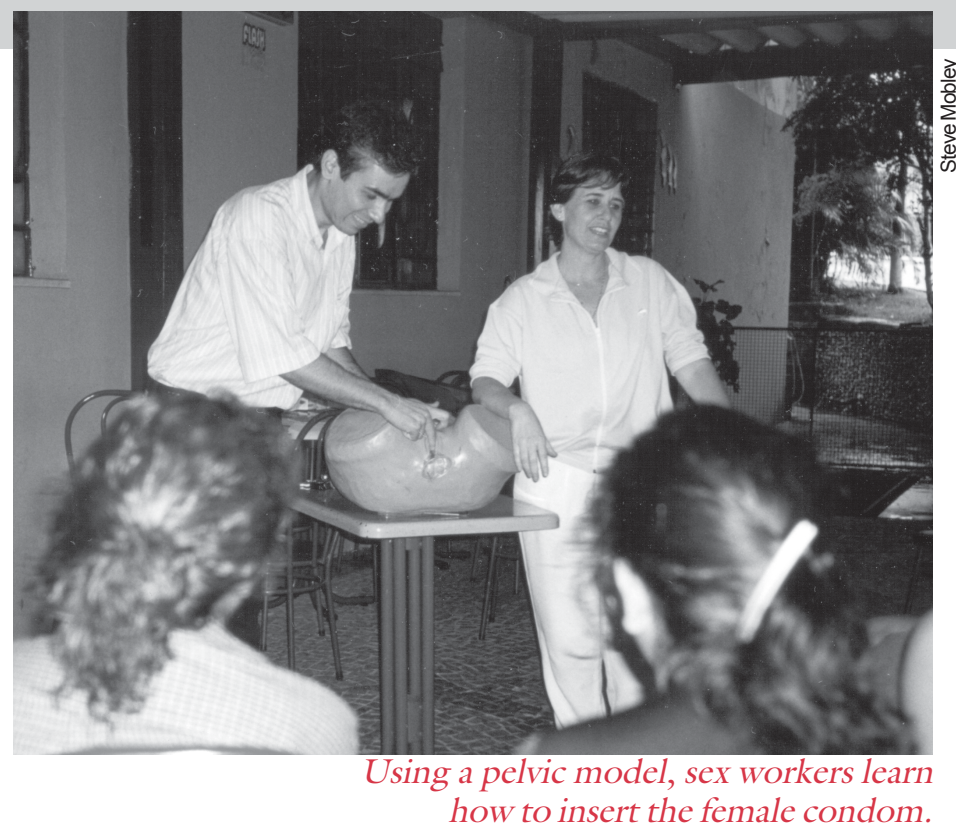

\section{Study Methods}

The study design was a pre-/post-intervention evaluation. The researchers collected crosssectional data from convenience samples of female sex workers at baseline $(\mathrm{n}=21 \mathrm{l})$ and follow-up ( $n=216)$. The follow-up survey was administered six months after the completion of the baseline survey. The samples of sex workers were drawn from four different socioeconomic settings in Campinas, in the state of São Paulo. The sites included a highend sex establishment (A); a sex establishment that caters to a middle-income clientele (B); a sex establishment located in a high-crime, red light district $(\mathrm{C})$; and selected streets and park areas in Campinas' commercial downtown district (D). To complement the quantitative data, the researchers conducted in-depth interviews with 20 women who participated in the final survey. 


\section{Intervention Components}

The intervention consisted of promotional, educational, and sales activities. The project team and the local social marketing organization, DKT, identified sales outlets near each study site, such as pharmacies, sex work establishments, and nightclubs, that agreed to sell the female condom. ${ }^{1}$ The project promoted the device through theatrical street performances and in selected sex establishments. Following the performances, the actors provided the audience with female and male condoms and information on the female condom, which included a list of nearby sales outlets. DKT also promoted the female condoms through several news stories in popular magazines and newspapers.

Every two weeks the project team conducted educational activities with small groups of sex workers from each study site (about 12 visits per site over the course of the intervention). The sessions included informal discussions on STI/ HIV prevention and reproductive health. A pelvic model was used to demonstrate how to insert the female condom, and participants were given the opportunity to practice with the model, ask questions, and discuss relevant issues.

A result of the educational activities was the establishment of the "Help Line." This was a cell phone number that sex workers could call to talk with a health promoter about usage problems and health concerns, or about how to locate female condoms.

\section{Characteristics of the Study Population}

Most of the female sex workers in the sample were under 25 years of age, had less than a high school education, and were single. However, there were significant differences in socioeco-

${ }^{1}$ The price for a box of two female condoms established by DKT was approximately $\mathrm{R} \$ 5.00$ to $\mathrm{R} \$ 7.00$, equivalent to US\$2.55 to US\$3.57 (US\$1.28 to US\$1.79 each). nomic status between the streetbased sex workers (Site D) and those who worked in sex establishments (Sites A, B, and C). Women who worked in the streets and parks of downtown Campinas were older (average age 33 years) compared to the sex workers from the other three sites (average age 23 years). Women who worked on the street were twice as likely to be divorced, separated, or widowed than the women who worked in the sex establishments. Forty-three percent of the street-based sex workers had less than a fifth grade education compared to from 1 to 9 percent of those working in the sex establishments. Although there were differences between sites, there were no significant differences between baseline and follow-up respondents with regard to age, marital status, and education.

\section{Key Findings}

The number of ever-users of the female condom increased significantly. At baseline, 17 percent $(34 / 204)$ of the sex workers reported ever use of the female condom. This climbed to 51 percent $(109 / 214)$ of the women interviewed in the final survey $(\mathrm{p}<.001)$. As shown in Figure 1 , there were variations in ever-use of the female condom among the sites. For example, the proportion of women from Site $\mathrm{C}$ who had tried the female condom rose from five percent to 61 percent. The high proportion of women in Site D interviewed at baseline who had tried the female condom was likely the result of an earlier acceptability trial that distributed free female condoms via a local health post. The main reasons given for initial use were curiosity, prevention of HIV/ STIs, and partners' or clients' unwillingness to use the male condom.

The female condom offers some advantages over the male condom. Sex workers perceived a number of benefits to the female condom: the ability to have sex in any position without the device breaking or slipping, greater lubrication than the male condom (especially valued by women with several clients per day), and the 
ability to use it during menstruation and when the man is not fully erect. A few noted that the female condom could be used if the client does not like male condoms. According to a streetbased sex worker, "I go to the bathroom and insert the female condom without him noticing it. And I do not lose money and at the same time I protect myself." Sex workers said they introduce the female condom by highlighting its advantages over the male condom, such as its loose fit, that the man doesn't have to do anything, and that it can give them both pleasure.

Sex workers are more likely to use a female condom with a regular client than with a new or occasional client. Findings from the final survey show that nearly three-fourths (72 percent) of women who used a female condom within the last six months reported using one with a regular client, compared to 14 percent who used the female condom with a client they either didn't know well or not at all. More than a third (35 percent) said they used a female condom with a boyfriend. Some sex workers mentioned that they felt more comfortable using it with someone they trust rather than with a stranger.

Practice increases sex workers' comfort with the female condom. When consistent users were asked how many times it took to feel comfortable using the female condom, most said between two and five times. Comfort involved learning how to insert it correctly and overcoming embarrassment due to its size and shape. According to one sex worker, "In the beginning I was ashamed because of the size and to have to insert it in front of the client. It was terrible...I think by the fifth time I was not ashamed anymore."

\section{Figure 1 Ever-use of the female condom by site (Baseline 1999-Follow-up 2000)}

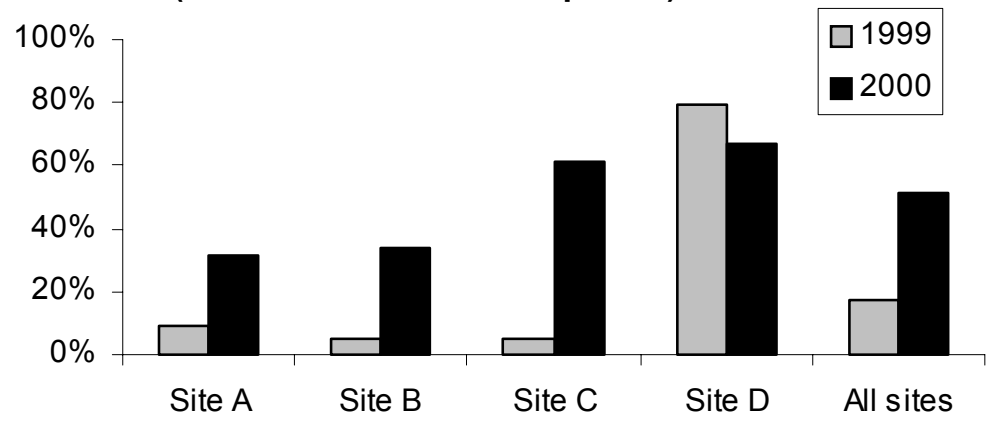

The majority of initiators are not currently using the female condom. Thirty-five percent of final survey respondents who had ever used the female condom claimed to be a current user. The largest proportion of women who reported current use was from Site D, the street-based sex workers (17/29 or 58 percent). This again may be due to previous exposure to an earlier intervention trial. About a fourth (29/109) of ever-users from the four sites said they had used the female condom at least once during their previous five sexual encounters, and 20 percent $(21 / 109)$ reported using it more than ten times during the last six months. Major complaints were difficulty of insertion and aesthetics (e.g., ugly appearance, noisy during use).

The intervention did not affect male condom use with new clients. About 97 percent of women in both the pre- and post-intervention samples reported that they always used a male condom with a new or occasional client.

However, there was a significant decrease in consistent condom use with intimate partners: 53 percent of the pre-intervention sample who had a boyfriend or spouse always used a male condom compared with 37 percent of the postintervention sample $(\mathrm{p}<0.01)$.

\section{Reported levels of protected sex did not} improve between baseline and final results. When asked about protected vaginal sex in the previous two weeks, 83 percent of the women in the baseline survey said they always used either a male or female condom with all of their partners. In the final survey, a significantly smaller proportion of women (69 percent) reported that they always used protection $(\mathrm{p}<.001)$.

\section{Less than a fourth (24 percent) of users} actually bought a female condom. Most women reported using condoms they received for free. All of the women who purchased the female condom were willing to pay at most US\$1.32 for each one; this dropped to 40 percent when the hypothetical price rose to US\$1.70. In contrast, the price of a male condom at the time of the study was US\$0.22. 


\section{Discussion and Conclusion}

Although the study lacked a control group, it is likely that the intervention, which focused on increasing access to the female condom and information about it, prompted more women to try the product. Contrary to male condom use, the study found that the sex workers were more likely to use the female condom with a partner they knew and trusted. The study did show that consistent male condom use with new partners remained very high after the intervention but decreased among women with boyfriends or spouses. It is possible that some of this decrease may be the result of using a female condom instead of a male condom with intimate partners.

Yet despite the educational and promotional activities that were designed to respond to barriers to use, there is no evidence that the intervention led to a sizeable proportion of women using the female condom consistently nor to an overall increase in women using protection (either male or female condoms) for each sex act with all partners. There may be several reasons for this. First, there were fewer than expected female condom promotional activities conducted by the social marketing organization at the study sites. Second, during the project period there was a severe downturn in the economy that likely affected sex workers' ability to buy female condoms, which sold for more than six times the price of a male condom. A third reason may be that as a result of increased rapport between the researchers and the study population at the time of the final survey, there may have been a greater willingness to answer questions about protected sex more honestly, which resulted in a lower figure compared to the baseline survey.

Although some sex workers believe the female condom offers advantages over the male condom, the nature of the product (e.g., its size and appearance) serves as a barrier to near universal use among this population of sex workers. It remains unclear whether a more intense promotional intervention and less prohibitive market conditions would lead to more frequent use. Future investigations should focus on interventions that offer the female condom at prices similar to the subsidized male condom, combined with educational and promotional activities that highlight its advantages for sex workers and foster practice to gain confidence about using the product. Such interventions should also build upon sex workers' preference for using the female condom with regular clients and boyfriends, partners with whom male condom use has been problematic because of its association with a lack of trust and intimacy.

October 2001

\section{References}

Berquó, E., R. Barbosa, and S. Kalckman. 1999. Aceitabilidade do Condom Feminino em Contextos Diversos. Relatório Final. CEBRAP, NEPO/ UNICAMP e CN DST/Aids.

Kerrigan, D. et al. 2000. The Female Condom: Dynamics of Use in Urban Zimbabwe. Washington, DC: Horizons, Population Council.

Slaviero, R. et al. 2000. Estudo da Aceitabilidade do Condom Feminino por Profissionais do Sexo no Município de Campinas, SP, Brasil. Relatório Final. Prefeitura Municipal de Campinas-COAS e Population Council do Brasil- December.

World Health Organization (WHO). 1997. The Female Condom: A Review. Geneva, Switzerland.

Study investigators are Loren Galvão, formerly of the Population Council, Brazil; Juan Diaz, Population Council, Brazil; Steven Mobley, formerly of Horizons / PATH; Francisco Cabral, Reprolatina; Nádia Marchi, University of Campinas; and Maria Silvia Fruet, consultant.

\section{Hqrizons}

Population Council/Horizons

Communications Unit

4301 Connecticut Avenue, NW

Suite 280

Washington, DC 20008 USA
UsAID This publication was made possible through support provided by the Global Bureau of Health/HIV-AIDS, U.S. Agency for International Development, under the terms of Award No. HRN-A-00-97-00012-00. The opinions expressed herein are those of the authors and do not necessarily reflect the views of the U.S. Agency for International Development. 